\title{
Cytokinin preconditioning enhances multiple shoot regeneration in Pongamia pinnata (L.) Pierre - a potential, non-edible tree seed oil source for biodiesel
}

\author{
Srinivas Belide ${ }^{1} \bowtie \cdot$ Ramgopal Rao Sajjalaguddam $^{1} \cdot$ Anitha Paladugu $^{1}$ \\ 1Department of Biotechnology, Sreenidhi Institute of Science and Technology, Yamnampet, Andhra Pradesh, India \\ $\triangle$ Corresponding author: srinivas.csiro@gmail.com \\ Received April 12, 2010 / Accepted August 27, 2010 \\ Published online: November 15, 2010 \\ (C) 2010 by Pontificia Universidad Católica de Valparaíso, Chile
}

\begin{abstract}
An efficient, highly reproducible protocol for multiple shoot induction and plant regeneration of Pongamia pinnata has been successfully developed using cotyledonary node explants. This study also demonstrates that preconditioning of explant stimulates production of multiple shoots from cotyledonary nodes of $P$. pinnata. The highest direct shoot regeneration (90\%) with an average of 18.4 \pm 3.1 shoots/explant were obtained when cotyledonary node explants were excised from seedlings germinated on Murashige and Skoog (MS) media supplemented with benzyladenine (BA) $1 \mathrm{mg} \mathrm{l}^{-1}$, and subsequently cultured on MS media with $1 \mathrm{mgl}^{-1}$ thidiazuron (TDZ). Scanning electron microscope observations of cotyledonary node (CN) explants excised from pre-conditioned and normal seedlings, revealed larger buds with rapid development in BA-preconditioned CN explants. The addition of adenine sulphate significantly increased the average number of shoots per explant. The highest direct shoot regeneration (93\%) with an average of $32.2 \pm 0.93$ shoots/explant was obtained from BApreconditioned $\mathrm{CN}$ when cultured on MS media supplemented with $1 \mathrm{mg} \mathrm{l}^{-1}$ TDZ and $200 \mathrm{mg} \mathrm{I}^{-1}$ adenine sulphate (ADS). Repeated shoot proliferation was observed from BA preconditioned CN explants up to 3 cycles with an average of 15 shoots/explant/cycle when cultured on MS media supplemented with $1 \mathrm{mgl}^{-1} \mathrm{TDZ}$ and $150 \mathrm{mg} \mathrm{l}^{-1}$ L-glutamine, thus producing 45 shoots/CN explant. Shoots were elongated on hormone free MS media and rooted on $1 / 2$ MS media supplemented with 1 $\mathrm{mg} \mathrm{l}^{-1}$ of IBA. Rooted shoots were successfully acclimatized and established in soil with $80 \%$ success. The highly regenerative system developed in this investigation for this important tree could be a useful tool for genetic transformation.
\end{abstract}

Keywords: benzyladenine, cotyledonary node, multiple shoot induction, scanning electron microscopy, thidiazuron.

\section{INTRODUCTION}

Pongamia pinnata (L.) Pierre (Syn. Pongamia glabra Vent.) is a multipurpose legume tree indigenous to the Indian subcontinent, south East Asia and one of the non-edible oil yielding tree with high potential for seed yield ( 20,000 seeds/tree). All parts of this plant have been traditionally used as crude drugs for the treatment of tumors, piles, skin diseases, wounds and ulcers. Its extracts possess significant antidiarrhoeal (Shoba and Thomas, 2001), antiplasmodial (Simonsen et al. 2001) and antiinflammatory (Srinivasan et al. 2001) activities. The seed is source of oil $(30-40 \% \mathrm{w} / \mathrm{w})$ and other number of bioactive compounds such as Pongamol and Karanjin, which makes the oil non suitable for edible purpose. Recently, $P$. pinnata has been recognized as a viable source of oil for the production of biodiesel and proved its potential (Karmee and Chadha, 2005; Meher et al. 2006). The composition of the seed oil and the properties of Pongamia fatty acid methyl esters (FAMEs) meet North American and European industry standards (Azam et al. 2005), however the pour point $\left(2.1^{\circ} \mathrm{C}\right)$ and cloud point $\left(8.3^{\circ} \mathrm{C}\right)$ are satisfactory for tropical regions of the world. Besides the advantage of not being a food crop, Pongamia can be grown on low agriculturally productive lands not suitable for food crops, particularly lands with high levels of salt, low soil fertility and little water. In addition, through its ability to capture and convert nitrogen from the air, and phosphorus through mycorrhizal interactions on its roots 
this legume tree enriches soils with low nitrogen levels and eliminates the need for nitrogen fertilizer (Scott et al. 2008).

Despite the multipurpose utility of Pongamia, attempts have never been made to improve the plant either by horticultural or biotechnological approaches and there is crucial need to develop quality planting material with enhanced seed yield, oil content and fatty acid composition. Genetic engineering and plant transformation technology can be applied to change the fatty acid profile, silence the genes responsible for the production of toxic Pongamol and Karanjin in seeds etc. demands efficient regeneration system, preferably from explants amicable for Agrobacterium mediated transformation. Commercial scale planting of Pongamia is also hampered by several factors like low viability of seeds and susceptibility to Rhizoctonia hiemalis (Edwards and Naithani, 1999).

Protocols for micropropgation in $P$. pinnata using mature tree derived axillary meristems were reported (Sujatha and Hazra, 2007). However, use of seedling explants is advantageous for transformation and or micropropagation, due to easy planning of experiments, reduction in contamination during tissue culture and reduction in labor and maintenance costs. The objective of the study was to induce multiple shoots and regenerate whole plant from cotyledonary node (CN). We also examined the effects of benzyladenine (BA) pre-conditioning, addition of adenine sulphate (ADS) and L-glutamine (L-g) in the regeneration and proliferation response. Scanning electron microscopy (SEM) observations were made in order to clearly establish the beneficial effect of BA preconditioning at the pre-explant stage in relation to multiple shoot induction from cotyledonary node.

\section{MATERIALS AND METHODS}

Seeds were collected from mature pods of locally grown Karanja ( $P$. pinnata L. Pierre) plant. After their removal from pods, seeds of uniform size and shape were selected, washed thoroughly under tap water for 10-15 min followed by a 1 min rinse in $70 \%$ ethanol. Seeds were surface sterilized with $0.25 \%$ mercuric chloride $\left(\mathrm{HgCl}_{2}\right)$ solution for $6 \mathrm{~min}$. After rinsing with sterile distilled water for four to five times, seeds were inoculated in $50 \mathrm{ml}$ test tubes containing $15 \mathrm{ml}$ of Murashige and Skoog medium (MS) (Murashige and Skoog, 1962) and MS medium supplemented with $1 \mathrm{mg}^{-1}$ of BA. All the seeds were incubated at $25 \pm 2^{\circ} \mathrm{C}$ in dark for $10-12$ days for germination.

Table 1. Effect of different concentrations of BA and TDZ on the frequency of shoot induction and average number of shoots from normal and preconditioned CN explants of $P$. pinnata (after 4 weeks of culture) on MS media.

\begin{tabular}{|c|c|c|c|c|c|}
\hline \multicolumn{2}{|c|}{$\begin{array}{c}\text { Plant growth } \\
\text { Regulators } \\
\left(\mathrm{mg}^{\mathrm{l}-1}\right)\end{array}$} & \multirow[t]{2}{*}{$\begin{array}{l}\text { \% Shoot Induction } \\
\text { (Mean } \pm \text { S. E.) }\end{array}$} & \multirow[t]{2}{*}{$\begin{array}{l}\text { Mean No. } \\
\text { of shoots/ } \\
\text { explant }\end{array}$} & \multirow[t]{2}{*}{$\begin{array}{c}\% \text { Shoot } \\
\text { Induction } \\
\text { (Mean } \pm \text { S. E.) }\end{array}$} & \multirow[t]{2}{*}{$\begin{array}{c}\text { Mean No. } \\
\text { of shootsI } \\
\text { explant }\end{array}$} \\
\hline BA & TDZ & & & & \\
\hline \multicolumn{2}{|c|}{ Control } & 0.0 & 0.0 & 0.0 & 0.0 \\
\hline 0.5 & -- & $40 \pm 1.15^{f}$ & $3.4 \pm 0.45^{\mathrm{e}}$ & $74 \pm 2.14^{\mathrm{e}}$ & $7.5 \pm 1.3^{\mathrm{e}}$ \\
\hline 1 & -- & $59 \pm 1.70^{b}$ & $7.3 \pm 0.92^{b}$ & $85 \pm 2.45^{b}$ & $12.3 \pm 2 .^{b}$ \\
\hline 2 & -- & $50 \pm 1.44^{c}$ & $5.7 \pm 1.22^{c}$ & $80 \pm 2.31^{c}$ & $9.1 \pm 1.6^{d}$ \\
\hline 3 & -- & $45 \pm 1.30^{c}$ & $4.5 \pm 0.62^{d}$ & $76 \pm 2.19^{d}$ & $8.5 \pm 1.3^{\mathrm{e}}$ \\
\hline-- & 0.5 & $48 \pm 1.39^{d}$ & $4.3 \pm 0.70^{d}$ & $80 \pm 2.3^{c}$ & $10.5 \pm 2.5^{c}$ \\
\hline-- & 1 & $64 \pm 1.85^{a}$ & $8.6 \pm 0.29^{a}$ & $90 \pm 2.60^{\mathrm{a}}$ & $18.4 \pm 3.1^{\mathrm{a}}$ \\
\hline-- & 2 & $58 \pm 1.67^{b}$ & $6.2 \pm 1.26^{\mathrm{c}}$ & $85 \pm 2.45^{b}$ & $12.6 \pm 2.2^{b}$ \\
\hline-- & 3 & $48 \pm 1.39^{d}$ & $5.7 \pm 1.48^{\mathrm{c}}$ & $78 \pm 2.25^{d}$ & $9.5 \pm 2.3^{d}$ \\
\hline
\end{tabular}


Cotyledonary node $(0.5-1.0 \mathrm{~cm})$ consisting of $2-4 \mathrm{~mm}$ of epicotyl and hypcotyl tissues with one or two intact cotyledons attached or trimmed to half of its original size is used in this study were excised both from axenic seedlings (10-12 cm) grown in dark on MS and MS+BA media. CN explants excised from seedlings grown on MS and MS+BA media were cultured on MS media supplemented with different growth hormones such as thidiazuron (TDZ) (0.5-3 $\left.\mathrm{mg} \mathrm{l}^{-1}\right)$, benzyladenine (0.5-3 $\mathrm{mg} \mathrm{l}^{-1}$ ) and with or without addition of adenine sulphate (ADS) and L-glutamine. All the media were adjusted to $\mathrm{pH} 5.8$ before addition of (0.8\%) agar (HiMedia India Ltd.), dispensed in to baby food jars $(5.7 \times 10.2 \mathrm{~cm})$ in 40 $\mathrm{ml}$ aliquots and sterilized at $121^{\circ} \mathrm{C}$ for $20 \mathrm{~min}$. All the cultures were incubated in a culture room maintained at $25 \pm 2^{\circ} \mathrm{C}$ under 16/8 hrs light/dark regime, $45 \mu \mathrm{mol} \mathrm{m} \mathrm{m}^{-2} \mathrm{~s}^{-1}$ irradiance level provided by cool white fluorescent tubes (Philips, Mumbai, India) with $55-60 \%$ relative humidity $(\mathrm{RH})$. CN explants were sub cultured on to fresh media for every two weeks and the results were scored after four weeks of culture.

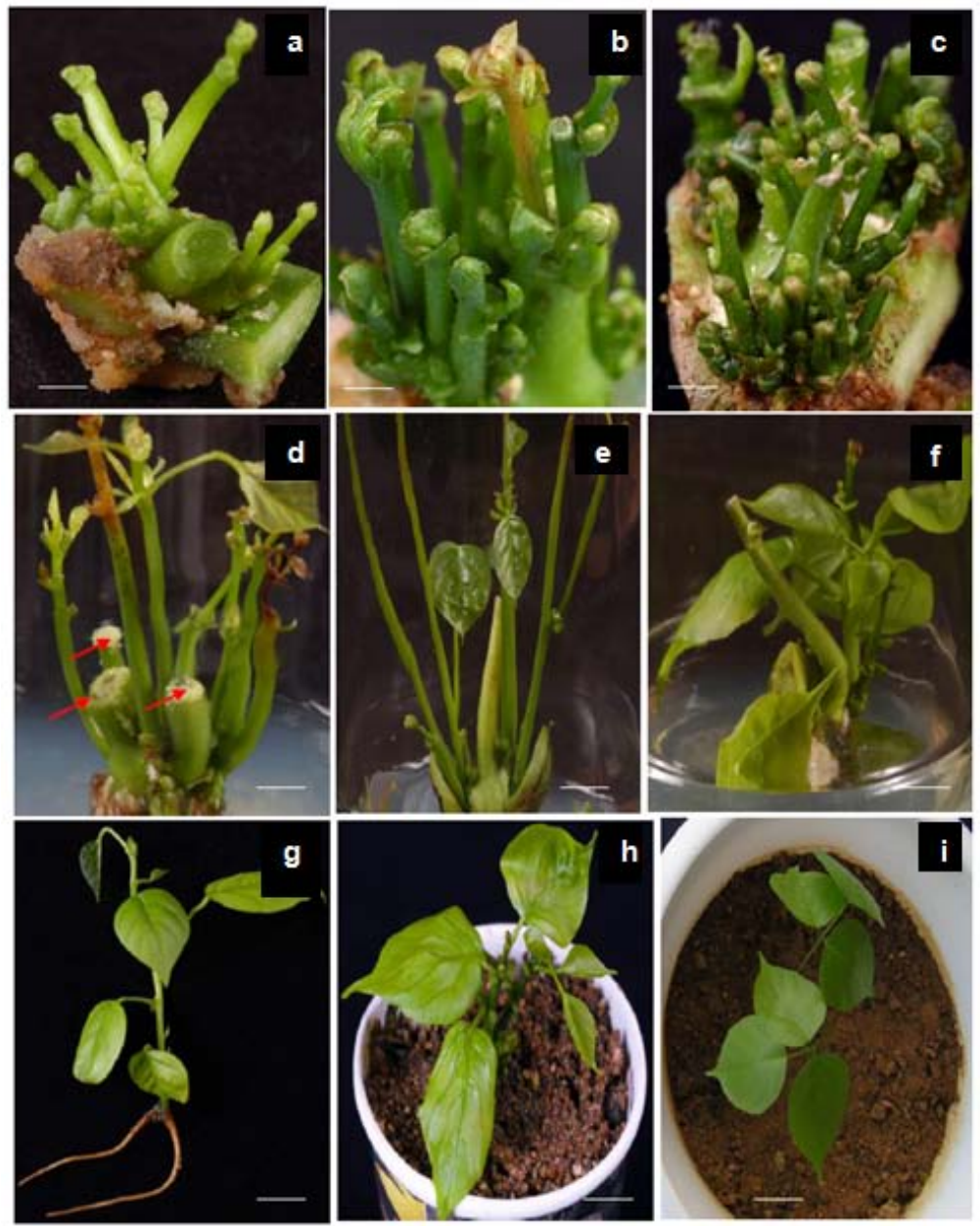

Fig. 1 Multiple shoot induction and plant regeneration from $C N$ of $P$. Pinnata $L$. (a-b) Multiple shoot initiation from pre-conditioned $\mathrm{CN}$ after 2 and 3 week culture on $\mathrm{MS}+1 \mathrm{mg} \mathrm{I}^{-1}$ of $\mathrm{BA}$ respectively. (c) Multiple shoot from pre-conditioned $\mathrm{CN}$ on $\mathrm{MS}+1 \mathrm{mg} \mathrm{l}^{-1}$ of TDZ $+200 \mathrm{mg} \mathrm{l}^{-1}$ ADS. (d) Initiation and development of new shoots after excision of first cycle shoots from CN (arrow). (e-f) Elongation of regenerated shoots on hormone free MS media with original explant. (g) Rooting of regenerated shoot on MS media supplemented with $1 \mathrm{mg} \mathrm{I}^{-1}$ of IBA, after two weeks of culture. $(\mathrm{h}-\mathrm{i})$ Acclimatized plants in pot. (Bar in $(\mathrm{a}-\mathrm{c})=0.5 \mathrm{~cm} ;(\mathrm{d}-\mathrm{f})=1 \mathrm{~cm} ;(\mathrm{g}-\mathrm{h})=2.0 \mathrm{~cm}$ and $\mathrm{i}=2.5 \mathrm{~cm})$.

Multiple shoots $(1.5-2 \mathrm{~cm})$ originating from in and around of preconditioned $\mathrm{CN}$ region were separated and sub cultured on to fresh MS media without any hormones for shoot elongation. The remaining portion of the $\mathrm{CN}$ explant along with shoot buds $(<1 \mathrm{~cm})$ was transferred again on to fresh MS media 
supplemented with TDZ and used repeatedly up to 2-3 cycles. CN isolated from normal seedlings were used for 1 or 2 times for the induction of multiple shoots.

Elongated, well developed shoots (3-5 cm long) with 3-5 leaves were excised and transferred individually on to $1 / 2 \mathrm{MS}$ medium supplemented with different concentrations of indole acetic acid (0.5-3 $\left.\mathrm{mg} \mathrm{l}^{-1}\right)$ and indole butyric acid $\left(0.5-3 \mathrm{mg} \mathrm{l}^{-1}\right)$ for rooting. In vitro rooted shoots were washed thoroughly in running tap water before being transplanted into plastic pots containing sterilized soil and vermiculite (1:1). Plants were covered with transparent polyethylene bags to maintain adequate moisture and transferred to the plant growth chamber (Pooja Labs, Bombay) and maintained at $24 \pm 2{ }^{\circ} \mathrm{C}$ with 70 $80 \%$ relative humidity. After $2-3$ weeks the plantlets were transferred to pots containing normal garden soil until they were transplanted to field.
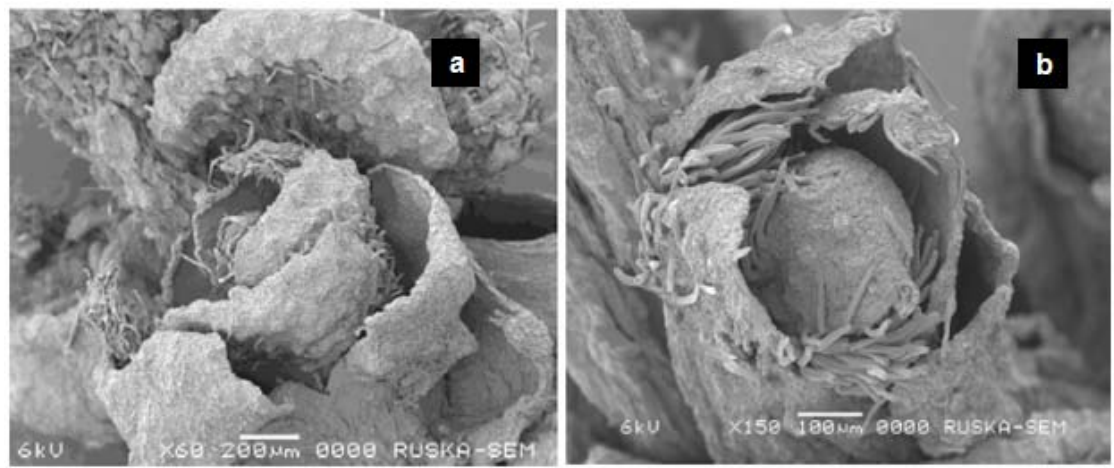

Fig. 2 Scanning electron micrographs of organogenesis from cotyledonary node explants of $P$. Pinnata

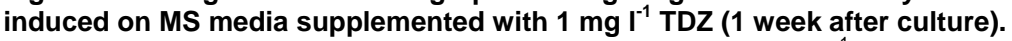

(a) Preconditioned $\mathrm{CN}$ excised from seedling grown on $\mathrm{MS}+1 \mathrm{mg}^{-1}$ (BA).

(b) CN excised from normal seedling grown on MS media.

\section{Scanning electron microscopy (SEM)}

Preconditioned and normal cotyledonary nodes after 7 days of culture on MS media supplemented with $1 \mathrm{mg} \mathrm{l}^{-1}$ of TDZ, were fixed in glutaraldehyde (2.5\%) in $0.05 \mathrm{M}$ phosphate buffer (pH 7.2) for 24 hrs at $4^{\circ} \mathrm{C}$ followed by $2 \%$ aqueous osmium tetroxide in $0.05 \mathrm{M}$ phosphate buffer $(\mathrm{pH} 7.2)$ for 2 hrs. After fixation, samples were dehydrated in a series of graded alcohol and dried to critical point with electron microscopy critical point drying (CPD) unit. Dried samples were mounted over the stubs with double sided conductivity tape. A thin layer of gold was applied over the sample using an automated sputter coater (JEOL JFC-1600) for about 3 min. Mounted samples were scanned using a scanning electron microscope (JOEL-JSM 5600, Japan) at an accelerated voltage of $6 \mathrm{kV}$ and the images were captured at various magnifications at RUSKA Labs, College of Veterinary Science, ANGR Agriculture University, Rajendranagar, Hyderabad.

\section{Data collection and statistical analysis}

Data on percentage of shoot regeneration were obtained after two and four weeks of culture. The average number of shoots/explant was collected from 28 day old cultures. In scoring number of shoots, each shoot consisted of apical meristem and leaves whose length from the base to meristem was at least 3-4 mm was considered and smaller shoots were not counted. A completely randomized design was used in all experiments. Analysis of variance and mean separation were carried out using Duncans Multiple Range Test (DMRT) and the significance was determined at the $5 \%$ level using MSTATC statistical software. 


\section{RESULTS AND DISCUSSION}

Pongamia seed has high oil content (approx. 40\%) and can grow on malnourished soils; its FAMEs as biodiesel are environmentally safe, non-toxic and biodegradable. Because of the advantages offered by Pongamia, it is fast becoming the focus of a number of biodiesel research programs. Some of the other advantages of Pongamia are: a higher recovery and quality of oil than other crops, no direct competition with food crops as it is a non-edible source of fuel, and no direct competition with existing farmland. As a legume it is also able to fix its own nitrogen from the soil, minimizing the need for added fertilizers. By using genetic engineering and plant transformation technology, it may be possible to alter the seed oil content by seed specific expression of genes involved in fatty acid synthesis for wider applications. $\mathrm{CN}$ have been used in the development of regeneration and transformation protocols in trees (Aslam et al. 2009). It is well documented that TDZ has been shown to be several folds more effective in enhancing in vitro adventitious shoot initiation and proliferation (Cuenca et al. 2000; Sriskandarajah et al. 2001). The effect of TDZ on $P$. pinnata shoot regeneration from seedling explants has hardly been exploited. In the present study, in addition to BA preconditioning, the effectiveness of amino purine cytokinin BA and TDZ was tested for the development of reliable protocol for regeneration using $\mathrm{CN}$ in $P$. pinnata.

Table 2. Influence of L-glutamine and adenine sulphate on multiple shoot induction from pre-conditioned CN after 4 weeks of culture on MS media supplemented with $1 \mathrm{mg} \mathrm{I}^{-1}$ of TDZ.

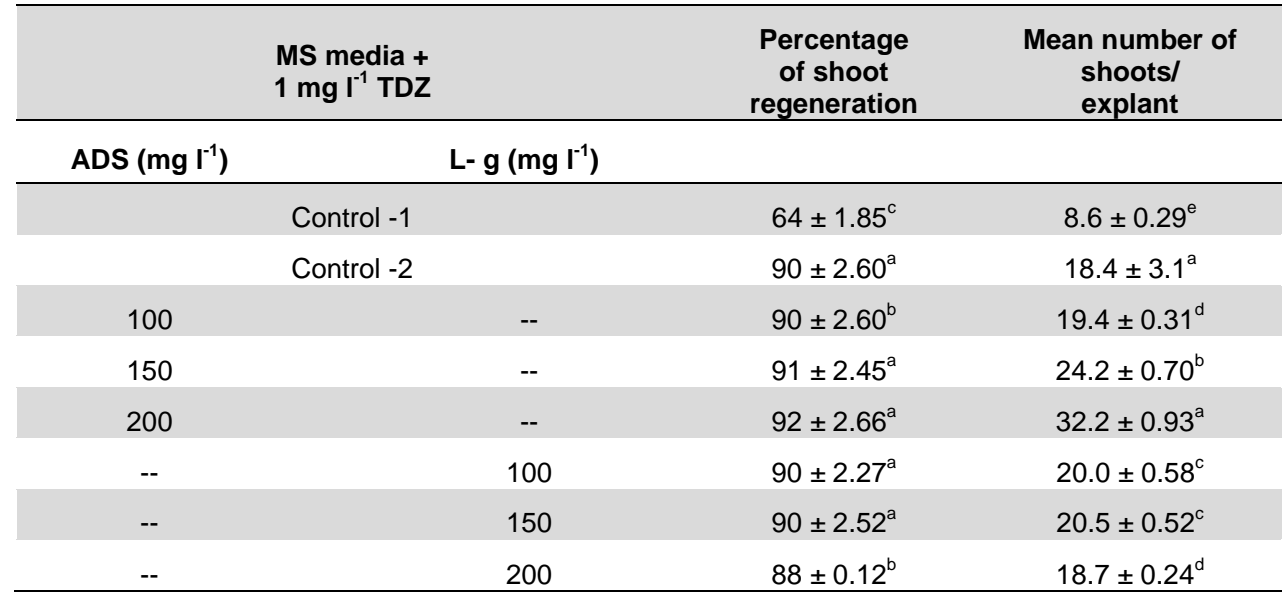

Control-1 Normal CN explant cultured on MS $+1 \mathrm{mg} \mathrm{l}^{-1}$ of BA.

Control-2 Preconditioned CN explant cultured on MS $+1 \mathrm{mg} \mathrm{I}^{-1}$ of TDZ.

Each experiment consisted of three replicates and data were represented as Mean $\pm \mathrm{S}$.E. Means followed by the same letters do not differ significantly at $\mathrm{p}<0.05$ according to Duncan's multiple range test.

\section{Influence of BA on seed germination of $P$. pinnata}

Radicle emergence was observed in seeds after 3 days of culture on MS media or MS media supplemented with $1 \mathrm{mg} \mathrm{l}^{-1}$ BA. In dark grown seedlings, etiolation was observed and the seedling attained $\sim 10 \mathrm{~cm}$ with in 10 days of culture. This suggested that BA at $1 \mathrm{mg} \mathrm{l}^{-1}$ does not restrict the germination of Pongamia seeds and the frequency of germination was $80-85 \%$. Further increase in the concentration of BA (2-3 $\left.\mathrm{mg} \mathrm{I}^{-1}\right)$ did not affect the seed germination significantly, but shoot appeared to be developmentally suppressed (Data not shown). 


\section{Effect of BA and TDZ on multiple shoot induction from normal and preconditioned CN explants}

CN explants excised from seedlings grown on MS media, when cultured on MS supplemented with BA (0.5-3 $\left.\mathrm{mg} \mathrm{l}^{-1}\right)$ or TDZ (0.5-3 $\left.\mathrm{mg} \mathrm{l}^{-1}\right)$ resulted into multiple shoot formation with in 2-3 weeks. Among different BA (0.5-3 $\left.\mathrm{mg} \mathrm{l}^{-1}\right)$ and TDZ $\left(0.5-3 \mathrm{mg} \mathrm{l}^{-1}\right)$ concentration tested, BA at $1 \mathrm{mg} \mathrm{l}^{-1}$ and TDZ at $1 \mathrm{mg}$ $\mathrm{I}^{-1}$ induced multiple shoots in $59 \%$ and $64 \%$ of the cultures respectively (Table 1 ). Any further increase in BA ( $\left.>1 \mathrm{mg} \mathrm{l}^{-1}\right)$ and TDZ (> $\left.1 \mathrm{mg} \mathrm{l}^{-1}\right)$ concentrations led to decrease in number of shoot buds/explant and large percentage of shoots were weak, hyperhydrated with reduced number of leaves in contrast to the development of normal shoots obtained on MS with $1 \mathrm{mg} \mathrm{l}^{-1}$ BA or $1 \mathrm{mg} \mathrm{I}^{-1} \mathrm{TDZ}$. The optimal medium supplements for multiple shoot formation was either $1 \mathrm{mg} \mathrm{l}^{-1} \mathrm{BA}(7.3+0.92$ shoots/explant $)$ or $1 \mathrm{mg} \mathrm{l}^{-1}$ of TDZ $(8.6+0.29$ shoots/explant). Callus formation was also observed from the cut surfaces of $\mathrm{CN}$ explants cultured on shoot induction media supplemented with higher concentration of TDZ (3 $\left.\mathrm{mg} \mathrm{l}^{-1}\right)$. However, no shoot formation was observed when callus cultured on various combinations and concentrations of TDZ, BA and KN (Data not presented). Without the addition of BA or TDZ no shoot formation was observed in normal and preconditioned CN explants.

Preconditioned $\mathrm{CN}$ explants when cultured on MS+BA (0.5-3 $\mathrm{mg} \mathrm{I}^{-1}$ ) resulted in multiple shoot formation within two weeks of culture (Figure 1a). Of all the BA concentrations tested, maximum (85\%) frequency of shoot induction was observed on MS medium supplemented with $1 \mathrm{mg} \mathrm{I}^{-1}$ BA producing up to $12.3 \pm 2.1$ shoots per explant (Figure $1 \mathrm{~b}$ ). In Vigna angularies, BA was also found to be most effective in inducing adventitious shoot formation from $\mathrm{CN}$ explants when used in both seed germination medium and shoot induction medium (Avenido and Hattori, 2000). Addition of BA (1 mg I ${ }^{-1}$ ) during seed germination was reported to be sufficient enough for efficient induction of shoots from CN of Mungbean (Avenido and Hattori, 2001). Histological observation in this study revealed bigger and more advanced shoots in pre-conditioned explants over control. In the present study, the effect of adding BA at $1 \mathrm{mg} \mathrm{l}^{-1}$ during seed germination (pre-conditioning of the explant) proved to be beneficial for early multiple shoot induction from cotyledonary node. Bigger and developmentally more advanced buds with leaf primordia were observed (Figure 2a) in BA treated explants over that of control (Figure $2 b)$. In addition to advancing the process of regeneration, percentage of shoot induction was consistently higher when BA was used during seed germination in all treatments tested when compared to MS basal media. Although there is a report on multiple shoot induction from $\mathrm{CN}$ explants of Pongamia using BA (Sugla et al. 2007), the present study highlights the significance of BA preconditioning of $\mathrm{CN}$ explant which resulted into two fold increase in number of shoots/explant.

Preconditioned CN when cultured on MS media supplemented with different concentration of TDZ (0.5$3 \mathrm{mg} \mathrm{l}^{-1}$ ) resulted in enhanced multiple shoot regeneration when compared with normal CN cultured on MS+BA or TDZ and preconditioned CN cultured on MS+BA. Of all the TDZ concentrations tested, maximum (90\%) frequency of shoot induction was observed on MS medium supplemented with $1 \mathrm{mg} \mathrm{l}^{-}$ ${ }^{1}$ TDZ forming up to $\sim 20$ shoots per explant (Table 1). The most efficient treatment combination in terms of the proportion of shoot-producing explants and productivity per explant was reported in BA preconditioning followed by shoot induction with1 $\mathrm{mg} \mathrm{l}^{-1}$ of TDZ. A similar culture system has been reported from CN explants in Chestnut (San José et al. 2001). TDZ at different concentrations, in either $\mathrm{BA}$-preconditioned or normal $\mathrm{CN}$ induced more shoots/explant compared to BA indicating TDZ is more effective than BA in $P$. pinnata. Sujatha and Hazra (2007) also reported the effectiveness of TDZ in induction of multiple shoots from mature tree derived axillary meristems of $P$. pinnata.

\section{Effect of adenine sulphate and L-glutamine}

The regeneration protocol described above used normal and BA-preconditioned CN explants. BApreconditioned explants were found to be me more responsive over normal CN explants to BA or TDZ. Although the number of explants producing shoots reached up to $90 \%$ with an average of 20 shoots per explant, however, once shoots had reached $0.5-1 \mathrm{~cm}$, further development of these shoots was poor. The addition of ADS (100-200 $\left.\mathrm{mg} \mathrm{l}^{-1}\right)$ to preconditioned CN explants cultured on MS medium supplemented with TDZ further increased number of shoots per explant significantly from 20 to 32 (Table 2 and Figure 1c); however there was no significant improvement in percentage of shoot regeneration. Among all the ADS concentrations tested, the optimal ADS concentration was found to be $200 \mathrm{mg} \mathrm{l}^{-1}$ and further increase in ADS concentration led to decrease in number of shoots/explant. It has been demonstrated that adenine, adenosine and adenylic acid have cytokinin activity and are added to the culture media to improve growth or to reinforce the response. The benefits of adenine are often only noticed when it is associated with ammonium nitrate or cytokinins such as BAP or kinetin (Van Standen et al. 2008). Our results suggest that TDZ, in combination with ADS, improves the 
process of organogenesis. Adenine sulphate has been used for in vitro multiplication of Carica papaya (Schmildt et al. 2007). Addition of L-glutamine to the regeneration medium did not show any significant improvement in either percentage of shoot regeneration or number of shoots/explant; however shoot development with broad leaves with more vigor was observed. Repeated shoot proliferation was also observed from BA preconditioned CN explants when cultured on MS supplemented with $1 \mathrm{mg} \mathrm{I}^{-1} \mathrm{TDZ}$ and $150 \mathrm{mg} \mathrm{l}^{-1}$ L-glutamine (Figure $1 \mathrm{~d}$ ), up to 2-3 cycles with an average of 15 shoots from explants. The enhancement of growth rate by L-glutamine could be explained on the basis that L-glutamine provided a readily available source of nitrogen, the implication being that the formation of necessary carbon skeleton or the reduction of nitrate to ammonia is a limiting factor in the cells (Gamborg, 1970). These results are in agreement with the findings of Selvaraj at al. (2007), who studied the effect of Lglutamine on efficient shoot regeneration from cotyledons of cucumber via organogenesis.

Table 3. Effect of different concentrations of auxins on percentage of rooting and roots per shoot in $P$. pinnata cultured on $1 / 2$ MS media after 4 weeks of culture.

\begin{tabular}{llll}
\hline $\begin{array}{l}\text { Auxin } \\
\left(\mathrm{mg} \mathrm{l}^{-1}\right)\end{array}$ & & $\begin{array}{l}\text { Percentage } \\
\text { of rooting } \\
\text { (Mean } \pm \text { S.E.) }\end{array}$ & $\begin{array}{l}\text { Mean number } \\
\text { roots per shoot }\end{array}$ \\
\hline Control & 0 & 0.0 & 0.0 \\
\hline IBA & 0.5 & $41.4 \pm 1.21^{\mathrm{d}}$ & $2.1 \pm 0.08^{\mathrm{e}}$ \\
& 1 & $64.5 \pm 1.68^{\mathrm{a}}$ & $5.3 \pm 0.11^{\mathrm{a}}$ \\
& 2 & $47.3 \pm 1.47^{\mathrm{c}}$ & $3.1 \pm 0.07^{\mathrm{c}}$ \\
& 3 & $44.1 \pm 1.33^{\mathrm{c}}$ & $2.7 \pm 0.04^{\mathrm{d}}$ \\
\hline IAA & 0.5 & $35.6 \pm 0.98^{\mathrm{e}}$ & $1.5 \pm 0.03^{\mathrm{d}}$ \\
& 1 & $43.9 \pm 1.11^{\mathrm{c}}$ & $3.9 \pm 0.07^{\mathrm{b}}$ \\
& 2 & $35.7 \pm 1.55^{\mathrm{e}}$ & $2.4 \pm 0.05^{\mathrm{e}}$ \\
& 3 & $32.0 \pm 1.24^{\mathrm{e}}$ & $2.1 \pm 0.04^{\mathrm{e}}$ \\
\hline
\end{tabular}

Each experiment consisted of three replicates and data were represented as Mean \pm S.E. Means followed by the same letters do not differ significantly at $p<0.05$ according to Duncan's multiple range test.

\section{Elongation, rooting and hardening}

$\mathrm{CN}$ explants along with the induced shoots were subsequently transferred to plant growth regulator free media for shoot elongation (Figure $1 \mathrm{e}$ and Figure 1f). After 2-3 weeks, elongated shoots were excised and transferred to rooting media. CN explants cultured on MS+1 mg l-1 of TDZ and $150 \mathrm{mg} \mathrm{l}^{-1}$ L-glutamine were used for up to 2-3 cycles after harvesting the shoots for every 2-3 weeks. Isolated single shoots were treated with different concentration of IAA and IBA on $1 / 2$ MS medium for root induction. Root initiation was observed with in 2 weeks of culture but complete root development that were suitable for hardening took 3-4 weeks. IBA and IAA showed difference in root induction response. While IBA at $1 \mathrm{mg} \mathrm{l}^{-1}$ showed the best rooting response (64.5\%) on $1 / 2 \mathrm{MS}$ media with an average of 5.3 roots/shoot, indole-3-acetic acid (IAA) at the same concentration (1 mg/l) induced 3.9 roots/shoot with a frequency of $43.9 \%$ (Table 3 and Figure $1 \mathrm{~g}$ ). Similar rooting response in Pongamia was reported by Sugla et al. (2007) with $1 \mathrm{mg} \mathrm{l}^{-1}$ indole-3-butyric acid (IBA). There was no significant difference observed in rooting response of shoots regenerated from pre-conditioned and normal explants.

Plantlets with well-developed roots were successfully acclimatized (Figure $1 \mathrm{~h}$ and Figure 1i) and eventually transferred to field. Eighty five percent of the plantlets transferred to sterilized soil and vermiculite survived, while $80 \%$ of the plants transferred to soil survived. The entire procedure starting from seed germination, multiple shoot induction to establishment of plant under greenhouse conditions took approximately 14 weeks. 
We have been successful in developing an in vitro regeneration system from $\mathrm{CN}$ explants of potential biofuel plant of $P$. pinnata. In the present study we report a major improvement in number of shoots/explant and also highlight the repeated proliferation of shoots from BA-preconditioned CN explant up to 3 cycles with an average of 15 shoots/CN/cycle, producing $\sim 45$ shoots/CN. The ability of the treated explant to form multiple shoots is a prerequisite for efficient genetic transformation. This simple and efficient regeneration system can be adapted for mass propagation of elite varieties and for future genetic transformation studies in this economically important plant.

Financial support: Sreenidhi Institute of Science and Technology and Technical Education Quality Improvement Program (TEQIP) - World Bank.

\section{REFERENCES}

ASLAM, M.; SINGH, R.; ANANDHAN, S.; PANDE, V. and AHMED, Z. (2009). Development of transformation protocol for Tecomella undulata (Smith) Seem from cotyledonary node explants. Scientia Horticulturae, vol. 121, no.1, p. 119-121. [CrossRef]

AVENIDO, R.A. and HATTORI, K. (2000). Benzyladenine-induced adventitious shoot regeneration from hypocotyls of adzukibean (Vigna angularis Willd. Ohwi \& Ohashi). Plant Growth Regulation, vol. 31, no. 3, p. 147-153. [CrossRef]

AVENIDO, R.A. and HATTORI, K. (2001). Benzyladenine-preconditioning in germinating mungbean seedlings stimulates axillary buds in cotyledonary nodes resulting multiple shoot regeneration. Breeding Science, vol. 51, no. 5, p. 137-142. [CrossRef]

AZAM, M.M.; WARIS, A. and NAHAR, N.M. (2005). Prospects and potential of fatty acid methyl esters of some nontraditional seed oils for use as biodiesel in India. Biomass \& Bioenergy, vol. 29, no. 4, p. 293-302. [CrossRef]

CUENCA, B.; BALLESTER A. and VIEITEZ, A.M. (2000). In vitro adventitious bud regeneration from internode segments of beech. Plant Cell Tissue and Organ Culture, vol. 60, no.3, p. 213-220. [CrossRef]

EDWARDS, D.G.W. and NAITHANI, S.C. (1999). Seed and nursery technology of forest trees. New Delhi, New Age International, $328 \mathrm{p}$.

GAMBORG, O.L. (1970). The effects of amino acids and ammonium on the growth of plant cells in suspension culture. Plant Physiology, vol. 45, no. 4, p. 372-375. [CrossRef]

KARMEE, S.K. and CHADHA, A. (2005). Preparation of biodiesel from crude oil of Pongamia pinnata. Bioresource Technology, vol. 96, no. 13, p. 1425-1429. [CrossRef]

MEHER, L.C.; DHARMAGADDA, V.S.S. and NAIK, S.N. (2006). Optimization of alkali-catalyzed transesterification of Pongamia pinnata oil for production of biodiesel. Bioresource Technology, vol. 97, no. 12, p. 1392-1397. [CrossRef]

MURASHIGE, T. and SKOOG, F. (1962). A revised medium for rapid growth and bioassays with tobacco tissue cultures. Physiologia Plantarum, vol. 15, no. 3, p. 473-497.

SAN JOSÉ, C.M.; BALLESTER, A. and VIEITEZ, M. (2001). Effect of thidiazuron on multiple shoot induction and plant regeneration from cotyledonary node of chestnut. Journal of Horticultural Science and Biotechnology, vol. 76, no. 5, p. 588-595.

SCHMILDT, O.; SCHMILDT, E.R. and AMARAL, J.A.T. (2007). Sulfato de adenina na multiplicação in vitro de mamoeiro "Tainung 01". Scientia Agraria, vol. 8, no. 2, p. 141-147.

SCOTT, P.T.; PREGELJ, L.; CHEN, N.; HADLER, J.S.; DJORDJEVIC, M.A. and GRESSHOFF, P.M. (2008) Pongamia pinnata: An untapped resource for the biofuels industry of the future. Bioenergy Research, vol. 1, no. 1, p. 2-11. [CrossRef]

SELVARAJ, N.; VASUDEVAN, A.; MANICKAVASAGAM, M.; KASTHURIRENGAN, S. and GANAPATHI. A. (2007). High frequency shoot regeneration from cotyledon explants of cucumber via organogenesis. Scientia Horticulturae, vol. 112, no. 1, p. 2-8. [CrossRef]

SHOBA, F.G. and THOMAS, M. (2001). Study of antidiarrhoeal activity of four medicinal plants in castor-oil induced diarrhoea. Journal of Ethnopharmacology, vol. 76, no. 1, p. 73-76. [CrossRef]

SIMONSEN, H.T.; NORDSKJOLD, J.B.; SMITT, U.W.; NYMAN, U. PALPU, P.; JOSHI, P. and VARUGHESE, G. (2001). In vitro screening of Indian medicinal plants for antiplasmodial activity. Journal of Ethnopharmacology, vol. 74, no. 2, p. 195-204. [CrossRef]

SRINIVASAN, K.; MURUGANANDAN, S.; LAL, S.; CHANDRA, J.; TANDAN, S.K. and PRAKASH, V.R. (2001). Evaluation of anti-inflammatory activity of Pongamia pinnata leaves in rats. Journal of Ethnopharmacology, vol. 78, no. 2-3, p. 151-157. [CrossRef]

SRISKANDARAJAH, S.; FRELLO, S. and SEREK, M. (2001). Induction of adventitious shoots in vitro in Campanula carpatica. Plant Cell Tissue and Organ Culture, vol. 67, no. 3, p. 295-298. [CrossRef]

SUGLA, T.; PURKAYASTHA, J.; SINGH, S.K.; SOLLETI, S.K. and SAHOO, L. (2007). Micropropagation of Pongamia pinnata through enhanced axillary branching. In Vitro Cellular \& Developmental Biology-Plant, vol. 43, no. 5, p. 409-414. [CrossRef]

SUJATHA, K. and HAZRA, S. (2007). Micropropagation of mature Pongamia pinnata Pierre. In Vitro Cellular \& Developmental Biology-Plant, vol. 43, no. 6, p. 608-613. [CrossRef]

VAN STANDEN, J.; ZAZIMALOVA, E. and GEORGE, E.F. (2008). Plant growth regulators II: Cytokinins, their analogues and antagonist. In: GEORGE, E.F.; HALL, M.A. and DE KLERK, G.J. eds. Plant Propagation by Tissue Culture. $3^{\text {rd }}$ ed. Dordrecht, Springer, chapter 6, p. 205-226. 


\section{How to cite this article:}

BELIDE, S.; SAJJALAGUDDAM, R.R. and PALADUGU, A. (2010). Cytokinin preconditioning enhances multiple shoot regeneration in Pongamia pinnata (L.) Pierre - a potential, non-edible tree seed oil source for biodiesel. Electronic Journal of Biotechnology, vol. 13, no. 6. http://dx.doi.org/10.2225/vol13-issue6-fulltext-5 